\title{
Daily phosphate intake in preterm infants - reality versus ESPGHAN recommendations
}

\author{
Dr Magdalena Fuller, ST6; Dr Tracy Lawson and Dr Vennila Ponnusamy, Consultant Neonatologists \\ Neonatal Intensive Care Unit, St Peter's Hospital, Chertsey, UK
}

\section{Introduction}

$>$ Babies born under 32 weeks gestation or weighing $<1500 \mathrm{~g}$ are at higher risk of metabolic bone disease (MBD) of prematurity since maximal bone mineralisation occurs during third trimester in pregnancy

ESPGHAN recommends daily intake of $120-140 \mathrm{mg} / \mathrm{kg}$

$(3-3.5 \mathrm{mmol} / \mathrm{kg})$ of calcium and $60-90 \mathrm{mg} / \mathrm{kg}(1.2-2.9 \mathrm{mmol} /$

$\mathrm{kg}$ ) of phosphate

$>$ Our early feeding guideline with routine supplementation of prophylactic breast milk fortifier (BMF) for medium and high risk babies was introduced in 2015

We aimed to review daily phosphate and calcium intake with this new guideline

\section{Methods}

$>$ All neonates born in 2015 with birthweight < 1500g were reviewed using electronic medical records

$>$ Data on total daily calcium and phosphate intake through parenteral nutrition, including BMF and additional $\mathrm{NaH}_{2} \mathrm{PO}_{4}$ supplementation was collected together with bone profile results

$>$ Excluded: neonates who died, or were transferred elsewhere for on-going care within 7 days or while on parenteral nutrition

\section{Results}

\section{$>90$ infants reviewed}

Table 1 summarises the clinical and nutritional data

\begin{tabular}{|c|c|}
\hline$N=90$ & Median (IQ range) \\
\hline Gestational age in weeks & $27+5(26+3-29+6)$ \\
\hline Birthweight, grams & $952.5(800-1208.75)$ \\
\hline Days of parenteral nutrition & $7.5(6-11.75)$ \\
\hline $\begin{array}{l}\text { Days of additional } \mathrm{NaH}_{2} \mathrm{PO}_{4} \\
\text { supplementation }\end{array}$ & $35(23.5-56.25)$ \\
\hline Lowest serum total calcium, $\mathrm{mmol} / \mathrm{L}$ & $1.92(1.71-2.07)$ \\
\hline Lowest serum phosphate, $\mathrm{mmol} / \mathrm{L}$ & $1.49(1.24-1.79)$ \\
\hline Highest alkaline phosphatase, $\mathrm{mmol} / \mathrm{L}$ & 489 (391.75-660.75) \\
\hline
\end{tabular}

Table 1. Clinical and nutritional data of the whole cohort of 90 neonates

$100 \%$ received mother's breast milk, $78 \%$ received supplemental donor breast milk, and $47.8 \%$ received formula feeds

$89 \%$ received parenteral nutrition and $88 \%$ received additional $\mathrm{NaH}_{2} \mathrm{PO}_{4}$

MBD was diagnosed biochemically in 5\% (ALP >900)

Only $13 \%$ required $\mathrm{NaH}_{2} \mathrm{PO}_{4}$ at discharge and two

(2\%) required treatment with cholecalciferol

Subset analysis of 19 infants with complete medical records up to 34 weeks post menstrual age showed median daily phosphate intake of $64.3 \mathrm{mk} / \mathrm{kg}$ (Table 2)

\begin{tabular}{lll}
\hline $\mathbf{N}=19$ & $\begin{array}{l}\text { Daily phosphate } \\
\text { intake (average } \mathrm{mg} / \\
\mathrm{kg} / \text { day) }\end{array}$ & $\begin{array}{l}\text { Daily calcium intake } \\
\text { (average } \mathrm{mg} / \mathrm{kg} / \text { day) }\end{array}$ \\
\hline Parenteral nutrition & 22.4 & 25.3 \\
Expressed breastmilk & 17.6 & 30.6 \\
Nutriprem 1 & 38.5 & 51.6 \\
Nutriprem 2 & 26.4 & 48.9 \\
BMF & 27.6 & 46.1 \\
\hline
\end{tabular}

Table 2. Detailed analysis of daily calcium and phosphate intake in a subset of 19 neonates

\section{Conclusions}

$>$ We had good compliance with local feeding guideline with lower incidence of MBD

$>$ Detailed analysis of daily phosphate intake shows that it is only possible to achieve adequate intake through enteral route with additional $\mathrm{NaH}_{2} \mathrm{PO}_{4}$ supplementation Subsequently, new guideline on routine phosphate supplementation for high risk infants was introduced (Figure 1) for close monitoring for MBD and to consistently meet ESPGHAN recommendations

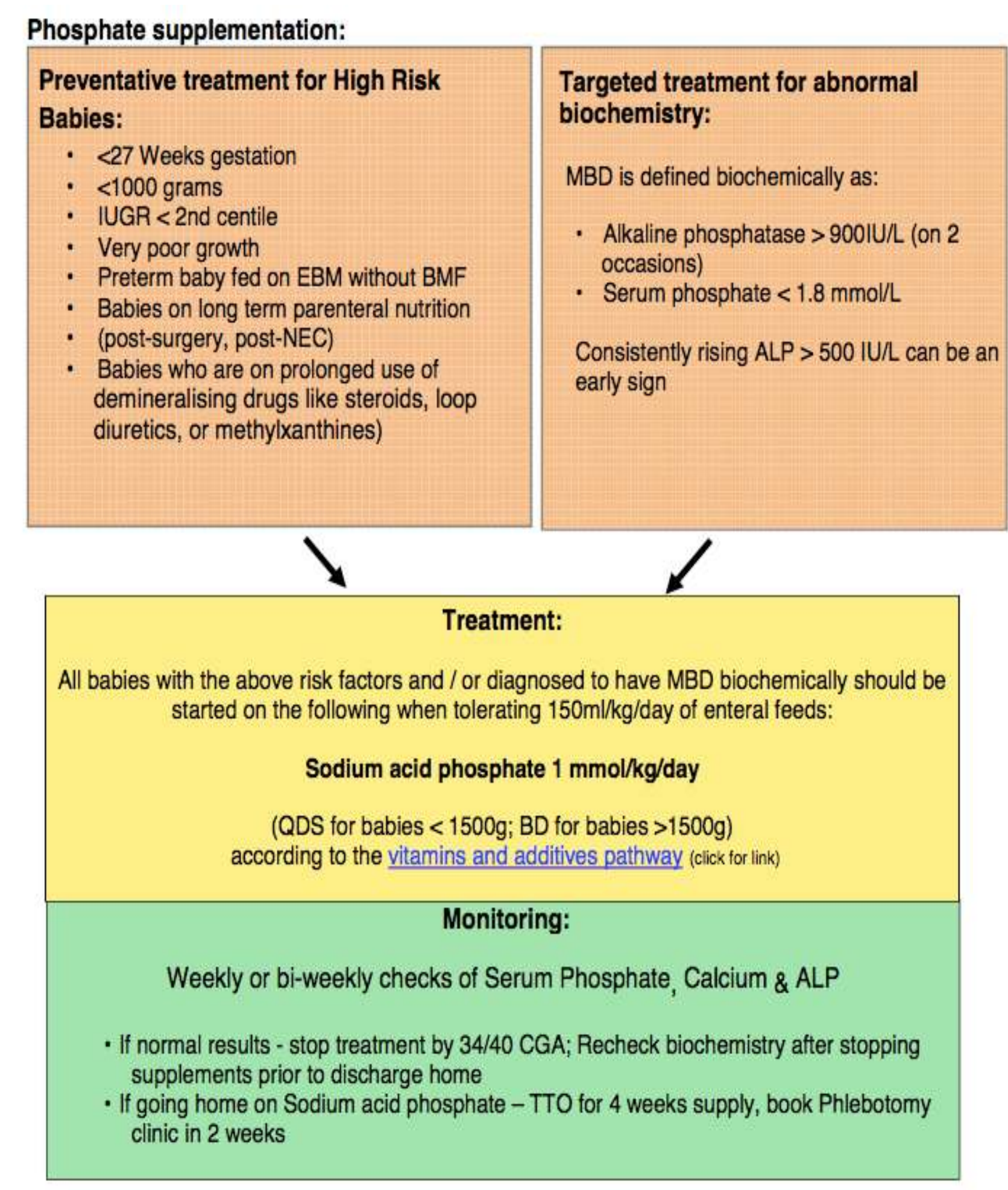

Management of Metabolic bone disease

Version 2.0, Dec 2016

Figure 1. Prophylactic Phosphate Supplementation for at risk infants 